\title{
KARAKTERISTIK KEPEMIMPINAN MADRASAH IBTIDIYAH
}

\author{
Muhammad Kadir ${ }^{1}$, Diarti Andra Ningsih ${ }^{2}$, Hasmiati $^{3}$, Laeli Qadrianti ${ }^{4}$ \\ ${ }^{1}$ Institut Agama Islam Muhammadiyah Sinjai \\ ${ }^{2}$ Institut Agama Islam Muhammadiyah Sinjai \\ ${ }^{3}$ Institut Agama Islam Muhammadiyah Sinjai \\ ${ }^{43}$ Institut Agama Islam Muhammadiyah Sinjai \\ E-mail: idrisgaligo7@gmail.com.Tlp:085756554657 \\ E-mail: diartiandiangkara@gmail.com.Tlp:082231895721 \\ E-mail: Miaelbugis@gmail.com.Tlp:085255835844 \\ E-mail: Laeliqadrianti@gmail.com.Tlp:081354743551
}

\begin{abstract}
Abstrak
Penelitian ini dilatar belakangi bahwa masih banyaknya kepala madrasah ibtidaiyah yang belum melakukan karakteristik kepemimpinan madrasah yang ideal, bahkan sampai ada yang sangat jauh dari harapan kepemimpinan madrasah yang diharapkan oleh segenap lingkungan madrasah ibtidaiyah yang ada di Kabupaten Sinjai. Selain itu, masih terdapat oknum kepala madrasah yang kadang melakukan pelanggaran-pelanggaran yang tentunya akan merugikan lembaganya dan mencederai karakter kepemimpinannya. penelitian ini difokuskan pada karakteristik kepemimpinan madrasah ibtidaiyah yang ada di kabupaten sinjai yang tentunya akan dijadikan tolak ukur bagi pemimpin-pemimpin madrasah untuk mengelolah lembaganya. Jenis penelitian ini menggunakan deskriptif kualitatif. Subyek dalam penelitian ini adalah kepala dinas pendidikan setempat, pakar pendidikan, kepala madrasah ibtidaiyah, wakil kepala madrasah bagian kesiswaan, guru dan peserta didik. Teknik pengambilan sampel yang digunakan adalah purposive sampling dan sampel jenuh. Teknik pengumpulan data menggunakan wawancara, observasi dan dokumentasi. analisis data menggunakan model Miles dan Hubberman dengan validitas data triangulasi. Hasil penelitian menyimpulkan bahwa pada dasarnya karakteristik kepemimpinan madrasah ibtidaiyah adalah suatu gambaran obyektif yang hampir terjadi di seluruh madrasah, hal itu dapat dilihat dari keterampilanketerampilan kepemimpinan madrasahibtidaiyah, kriteria-kriteria kepemimpinan madrasah, tugas dan peranan kepala madrasah ibtidaiyah sebagai pemimpin.
\end{abstract}

Kata Kunci: Karakteristik Kepemimpinan, Madrasah Ibtidaiyah.

\section{Pendahuluan}

Kepemimpinan pada dasarnya berarti kemampuan untuk memimpin; kemampuan untuk menentukan secara benar apa yang harus dikerjakan. Menurut Gibson, kepemimpinan merupakan kemampuan mempengaruhi orang lain, yang dilakukan melalui hubungan interpersonal dan proses komunikasi untuk mencapai tujuan. (James L Gibson, 1988: 334). Newstrom \& Davis berpendapat bahwa kepemimpinan merupakan suatu proses mengatur dan membantu orang lain agar bekerja dengan benar untuk mencapai tujuan. (Keith Davis, 1985:122). Sedangkan Stogdill berpendapat bahwa kepemimpinan juga merupakan proses mempengaruhi kegiatan kelompok, dengan maksud untuk mencapai tujuan dan prestasi kerja. (James L Gibson, 1988: 334).

Oleh karena itu, kepemimpinan dapat dipandang dari pengaruh interpersonal dengan memanfaatkan situasi dan pengarahan melalui suatu proses komunikasi ke arah tercapainya tujuan khusus atau tujuan lainnya. Pernyataan ini mengandung makna bahwa kepemimpinan terdiri dari dua hal yakni proses dan properti. Proses dari kepemimpinan adalah penggunaan pengaruh secara tidak memaksa, untuk mengarahkan dan mengkoordinasikan kegiatan dari para anggota yang diarahkan 
pada pencapaian tujuan organisasi. Properti dimaksudkan, bahwa kepemimpinan memiliki sekelompok kualitas dan atau karakteristik dari atribut-atribut yang dirasakan serta mampu mempengaruhi keberhasilan pegawai (Victor H. Vroom dan Jago, 1988: 34).

Pada umumnya kepala sekolah memiliki tanggung jawab sebagai pemimpin dibidang pengajaran dan pengembangan kurikulum, administrasi kesiswaan, administrasi personalia staf, hubungan masyarakat, administrasi school plant, perlengkapan dan oraganisasi sekolah.

Cara kerja kepala sekolah dan cara ia memandang peranannya dipengaruhi oleh kepribadiannya, persiapan dan pengalaman profesionalnya, dan ketetapan yang dibuat oleh sekolah mengenai peranannya kepala sekolah dibidang pengajaran. Pelayanan pendidikan dalam dinas bagi administrasi sekolah dapat memperjelas harapan-harapan atas peranan kepala sekolah.

Kepala Madrasah sebagai pimpinan tertinggi di suatu lembaga, memiliki peranan yang sangat vital dalam pengelolaan lembaga pendidikan, karena maju mundurnya lembaga berada dibawah tangung jawabnya.. Adanya kreatifitas kepala madrasah menjadi keniscayaan sehingga ia mampu memanej organisasi madrasah dengan baik dan benar. Implikasinya berupa keberhasilan secara menyeluruh, yaitu berupa out put dan adanya sinergitas dalam lingkungan pendidikan. Baik sinergitas seluruh tenaga edukasi dan karyawan, peserta didik, dan lingkungan masyarakatnya.

Penelitian ini dilatar belakangi bahwa masih banyaknya kepala madrasah ibtidaiyah yang belum melakukan karakteristik kepemimpinan madrasah yang ideal, bahkan sampai ada yang sangat jauh dari harapan kepemimpinan madrasah yang diharapkan oleh segenap lingkungan madrasah ibtidaiyah yang ada di Kabupaten Sinjai. Selain itu, masih terdapat oknum kepala madrasah yang kadang melakukan pelanggaran-pelanggaran yang tentunya akan merugikan lembaganya dan mencederai karakter kepemimpinannya. penelitian ini difokuskan pada karakteristik kepemimpinan madrasah ibtidaiyah yang ada di kabupaten sinjai yang tentunya akan dijadikan tolak ukur bagi pemimpin-pemimpin madrasah untuk mengelolah lembaganya.

\section{Metode}

Metode dalam penelitian ini yang dimaksud adalah cara yang digunakan peneliti untuk melakukan penelitian dan mendapatkan data yang akurat dari narasumber.

\subsection{Jenis Penelitian}

Dalam penelitian ini dapat diklasifikasikan sebagai penelitan lapangan (field research) yang bersifat deskriptif kualitatif, yaitu prosedur penelitian yang menghasilkan data deskriptif berupa katakata tertulis atau lisan dari orang-orang dan perilaku yang dapat diamati. (S. Samargono, 2004: 36.

Menurut Bogdan dan Taylor yang dikutip oleh Lexy J. Moleong dalam bukunya "Metodologi Penelitian Kualitatif" adalah sebagai prosedur penelitian yang menghasilkan data deskriptif berupa kata-kata tertulis dari orang-orang dan perilaku yang dapat diamati ( Lexy J. Moleong, 2005: 4). Jenis penelitian ini menggunakan logika berfikir induktif, dimana penelitian ini memiliki karakteristik bahwa datanya dinyatakan dalam keadaan sewajarnya atau sebagaimana adanya dengan tidak mengubah dalam bentuk simbol atau bilangan karena metode penelitian ini tidak menggunakan data statistik. (Ronny Kountur, 2004: 24).

Penelitian kualitatif ini bertujuan untuk memperoleh pemahaman yang autentik mengenai pengalaman orang-orang, sebagaimana dirasakan orang-orang yang bersangkutan. Adapun pendekatan yang digunakan adalah pendekatan berfikir, yaitu dengan memandang suatu kebijakan merupakan refleksi dari keinginan pembuat kebijakan merupakan babak sejarah yang terkait dengan waktu dan peristiwa.

\subsection{Subjek dan Objek Penelitian}

Sampel dari penelitaian kualitatif tidak menggunakan istilah populasi tetapi oleh Spradley dalam bukunya Participant Observation dinamakan "social situation" atau situasi sosial terdiri atas tiga elemen yaitu: tempat (place), pelaku (actors), dan aktifitas (activity) yang berinteraksi secara sinergis. (Ronny Kountur, 2004: 24). 
Pada penelitian kualitatif, peneliti memasuki situasi sosial tertentu, yang dapat berupa lembaga pendidikan tertentu, melakukan observasi dan wawancara kepada orang-orang yang dipandang tahu tentang situasi sosial tersebut. Penentuan sumber data pada orang yang diwawancarai dilakukan secara puposive, yaitu dipilih dengan pertimbangan dan tujuan tertentu. (Ronny Kountur, 2004: 24). Peneliti akan meminta rekomendasi dari berbagai pihak yang lebih tau tentang karakteristik kepemimpinan yang ada di Madrasah.

\subsubsection{Subyek Penelitian}

Subjek penelitian adalah informan yang lebih mengetahui permasalahan yang ingin diteliti dan dapat memberikan informasi tentang penelitian ini atau pengambilan sumber data dengan pertimbangan yakni yang dianggap paling tahu tentang apa yang diharapkan peneliti. (Sugiyono, 2010: 300).

\subsubsection{Objek Penelitian}

Objek penelitian adalah suatu atribut atau sifat atau nilai dari orang, objek atau kegiatan yang mempunyai variasi tertentu yang ditetapkan oleh peneliti untuk dipelajari dan ditarik kesimpulannya. (Sugiyono, 2010: 38). objek dalam penelitian adalah karakteristik kepemimpinan di madrasah.

\subsection{Tempat dan waktu Penelitian}

Adapun tempat penelitian adalah di Kabupaten Sinjai. Dan waktu penelitian dilaksanakan mulai dari bulan Januari hingga maret 2019.

\subsection{Tahap-Tahap Penelitian}

Penelitian ini menggunakan empat tahapan dalam penelitian diantaranya; Invention (tahap pra lapangan), discovery (tahap pekerjaan lapangan), interpretation (tahap data) dan explanation (penyusunan laporan). (Sugiyono, 2010: 83).

\subsection{Metode Pengumpulan Data}

menurut J.R. Raco informan adalah orang yang memiliki kemampuan untuk menceritakan pengalamannya atau memberikan informasi yang dibutuhkan, kemudian mereka juga benar-benar terlibat dengan gejala, peristiwa, dan hal-hal yang berkaitan dengan penelitian yang dilakukan. Ada tiga teknik pengumpulan data yang digunakan untuk mendapatkan informasi mengenai Karakteristik Kepemimpinan di Madrasah, yaitu:

\subsubsection{Wawancara/Interview}

Menurut Arikunto, wawancara atau interview adalah sebuah dialog yang dilakukan oleh si pewawancara (interviewer) untuk memperoleh informasi dari si terwawancara (informan). Interview digunakan oleh peneliti untuk menilai keadaan seseorang. (Suharsimi Arikunto, 2006:1550).

\subsubsection{Observasi}

Menurut Arikunto, observasi atau yang disebut pula dengan pengamatan, meliputi kegiatan pemuatan perhatian terhadap sesuatu objek dengan menggunakan seluruh alat indra. (Suharsimi Arikunto, 2006:156).

\subsubsection{Dokumentasi}

Di dalam melaksanakan metode dokumentasi, peneliti menyelidiki benda-benda tertulis seperti perangkat pembelajaran, hasil penilaian siswa, buku-buku, dokumen supervisi guru, notulen rapat, dokumentasi kegiatan peneliti di lapangan dan sebagainya. (Etta Mamang Sangadji dan Sopiah, 2010: 48)

\subsection{Triangulasi data}

Triangulasi adalah teknik keabsahan data yang memanfaatkan sesuatu yang lain diluar data itu untuk keperluan pengecekan atau sebagai pembanding terhadap data lapangan. ( Lexy J. Moleong, 2005: 178).

\subsection{Metode Analisis Data}

Teknik analisis data adalah proses menyusun data agar dapat ditafsirkan, dituliskan dalam bentuk kata-kata atau lisan. Data yang terkumpulkan dari beberapa narasumber yang ada di lapangan, sebelum penulis menyajikannya, terlebih dahulu akan dilakukan proses analisa agar nantinya data tersebut benar-benar dapat dipertanggung jawabkan kebenarannya. 


\section{Hasil dan Pembahasan}

Berikut hasil dan pembahasan dari penelitian ini, penulis akan menjelaskan mulai dari pengertian karakteristik dan kepemimpinan pendidikan, kemudian karakteristik kepemimpinan Madrasah Ibtidaiyah.

\subsection{Pengertian Karakteristik dan Kepemimpinan Pendidikan}

Karakteristik adalah sesuatu yang khas atau mencolok dari seseorang ataupun sesuatu benda atau hal. Karakteristik adalah mengacu kepada karakter dan gaya hidup seseorang serta nilai-nilai yang berkembang secara teratur sehingga tingkah laku menjadi lebih konsisten dan mudah di perhatikan. Pemimpin yang cerdas akan terlihat dari pola tingkah lakunya setiap hari dalam menjalankan kepemimpinan, dan tingkah laku tersebut dilakukan secara konsisten atau istiqomah, sehingga secara tidak langsung seiring dengan berjalannya waktu hal tersebut akan menjadi suatu karakter kepemimpinan,

Dengan melihat pengertian di atas, apabila kita ingin jelaskan karakteristik dalam bidang kepemimpinan madrasah, maka yang perlu di perhatikan adalah ciri-ciri, karakter, dan gaya kepemimpinan yang di jalangkan oleh seoarang kepala madrasah. Artinya bahwa ketika kita ingin mengetahui bagaimana karakteristik kepemimpinan suatu madrasah tentunya yang paling utama dan utama kita perhatikan adalah bagaimana ciri-ciri, karakter dan gaya kepemimpinan kepala madrasah dersebut dalam menjalankan roda kepemimpinannya.

Sedangkan kepemimpinan pada dasarnya berarti kemampuan untuk memimpin, kemampuan untuk menentukan secara benar apa yang harus dikerjakan. Menurut Gibson, kepemimpinan merupakan kemampuan mempengaruhi orang lain, yang dilakukan melalui hubungan interpersonal dan proses komunikasi untuk mencapai tujuan. (James L Gibson, 1988: 334).

Kepemimpinan secara umum didefinisikan sebagai kemampuan dalam kesiapan yang dimiliki oleh seseorang untuk dapat mempengaruhi, mendorong, mengajak, menuntun, menggerakkan, mengarahkan, dan kalau perlu memaksa orang atau kelompok agar menerima pengaruh tersebut dan selanjutnya berbuat sesuatu yang dapat membantu tercapainya suatu tujuan tertentu yang telah ditetapkan.

Kepemimpinan adalah proses mempengaruhi kegiatan-kegiatan kelompok yang diorganisir menuju kepada penentuan dan pencapaian tujuan (Ralp M.Stogdill). Kepemimpinan dalam organisasi berarti penggunaan kekuasaan dan pembuatan keputusan-keputusan (Robert Dubin).

Kepemimpinan adalah individu di dalam kelompok yang memberikan tugas pengarahan dan pengorganisasian yang relevan dengan kegiatan-kegiatan kelompok (Fred E.Fiedler).

Dari beberapa pengertian kepemimpinan pendidikan di atas penulis dapat simpulkan bahwa, kepemimpinan Pendidikan adalah kemampuan untuk menggerakkan pelaksanaan pendidikan, sehingga tujuan pendidikan yang telah ditetapkan dapat tercapai secara efektif dan efisien.

\subsection{Karakteristik Kepemimpinan Madrasah Ibtidaiyah}

Pada dasarnya karakteristik kepemimpinan madrasah ibtidaiyah adalah suatu gambaran obyektif yang hampir terjadi di seluruh madrasah, hal itu dapat dilihat dari keterampilan-keterampilan kepemimpinan madrasah, kriteria-kriteria kepemimpinan madrasah, tugas dan peranan kepala madrasah sebagai pemimpin. Untuk lebih jelasnya penulis akan uraikan sebagai berikut:

\subsubsection{Keterampilan-keterampilan kepemimpinan madrasah ibtidaiyah}

Adapun keterampilan-keterampilan kepemimpinan yang dimaksud terdiri dari skill in leadership, skill in human relationship, skill in group process, skill in personal administration, skill in evaluation. (Burhanuddin, 1994: 93).

Untuk lebih jelasnya mengenai keterampilan-keterampilan pendidikan yang dikemukakan oleh para ahli tersebut, maka akan diuraikan secara berturut-turut sebagai berikut:

a. Skill in leadership

Dengan kekuatan kedudukan (formalitas) saja tidak dapat menjamin seorang pimpinan dapat mengorganisir unit-unit organisasi maupun anggota keompok secara berhasil. Sikses tidaknya seorang pemimpin sangat ditentukan oleh kemampuannya dalam mengaplikasikan fungsi-fungsi 
kepemimpinannya ke dalam proses kerja sama administrative maupun supervise. Pada hakikatnya fungsi-fungsi kepemimpinan yang harus dijalankan itu meliputi : usaha mempengaruhi, mendorong, menggerakkan, membimbing dan mengarahkan orang lain agar orang tersbut mau menerima pengaruh itu serta secara suka rela / penuh antusias berbuat sesuatu untuk mencapai tujuan-tujuan yang ditetapkan. (Burhanuddin, 1994: 93-94).

Agar tujuan yang akan dirumuskan bersama ini dapat berhasil dengan baik, maka mereka diberi kesempatan untuk mengembangkan ide-ide, prosedur kerja dan bahan pembicaraan lainnya, dengan melalui "workshop", team-team atau dalam kepanitiaan.

Usaha-usaha di atas akan mempertinggi kreativitas guru-guru, karena mereka merasa mampu membuat keputusan-keputusan yang berharga, rencana-rencana yang bernilai dan menganggap pimpinan madrasah seperti seorang bapak yang bijaksana.

b. skill in human relationship

Di dalam kehidupan warga dalam madrasah tentu terdapat hubungan kemanusiaan yang tidak sehat, situasi semacam itu akan mempunyai pengaruh yang serius semacam itu akan mempunyai pengaruh yang serius terhadap perkembangan pendidikan dan pengajaran di madrasah.

Oleh karena itu, pemimpin yang bijaksana akan segera mengambil langkah-lagkah untuk berusaha menciptakan suasana emosional yang sehat bagi madrasah, sehingga tercipta perasaan kekeluargaan yang akrab dan bahagia yang memberi dorongan bekerja yang penuh gairah. Ada empat macam usaha untuk menciptakan hubungan kemanusiaan yang sehat, yaitu :

1. Menghormati tiap-tiap pribadi anggota staf.

Beberapa usaha untuk memenifestasikan penghormatan itu kepada tiap-tiap pribadi anggota staf, antara lain pimpinan hendaknya menunjukkan sikap kesungguhan untuk memperhatikan problema-problema yang mereka hadapi, ia hendaknya mendahulukan keinginan mereka dari pada keinginan sendiri, memberikan kesempatan dan memperhatikan ide-ide mereka, saran-saran mereka dan pendapat mereka, baik yang diajukan secara informal maupun dalam situasi yang formal.

2. Menghormati tiap-tiap pribadi murid

Beberapa usaha agar anak-anak itu merasa diterima dengan senang hati oleh guru-guru, maka guru-guru hendakya memberi perlakuan yang jujur dan adil tanpa memandang anak orang miskin dan anak orang kaya.

3. Mengumpulkan data-data

Pengumpulan data-datapribadi para anggota staf pengajaran dan non pegajaran yang sangat penting sekali bagi kepala madrasah untuk memberi bantuan-bantuan pemecahan persoalan pribadi bagi mereka.

4. Sikap ramah tamah

Sikap ramah tamah, rendah hati, lapang dada dan tabah hati dalam berusaha mendekati dan memecahkan problema pribadi mereka masing-masing, akan membantu meciptakan iklim emosional yang sehat di kalagan warga madrasah tersebut.

c. skill in group process

Keterampilan dalam proses ini sangat petin, karena hal ini dibutukan dalam mebangun dan megembangkan kerjasama. Iklim kerja sama itu biasanya melalui rapat-rapat madrasah, mereka ini hendaknya diberi kesempatan untuk meneliti program-program madrasah dan merencanakan dengan baik bagaimana cara mereka untuk menanggapi program tersebut.

Agar pelaksanaan itu sukses seperti yang diharapkan, maka ada beberapa usaha atara lain pimpinan hendaknya mengembangkan keterampilan dalam :

1. Merencanaka kerja kelompok yang efektif.

2. Membantu kelompok menganalisis prosedur.

3. Membantu kelompok menla prosedur.

4. Merencanakan cara yang lebih efektif untuk kerj sama mereka. 
Keterampilan dalam mengelola personalia ini merupakan tanggug jawab pimpinan, terutama dalam menyeleksi anggota staf. Prosedur yang perlu diperhatikan dalam menyeleksi anggota staf ini, ialah :

1. Susunlah bersama anggota staf tentng kualfikasi yang hrus dipenuhi oleh pelama.

2. Melaksanakan Penyaringan para calon agota staf.

3. Menyarankan calon-calon yang terbaik.

4. Mengadakan "induction program" atau "orientation program".

e. skill in evaluation

Keterampilan dalam mengadakan penilaian ini bermaksud ntuk membantu pimpinan dan anggota staf dalam membuat keputusan yang lebih bijaksana, yaitu keputusan yang berdasakan analisis dari bukti-bukti (data-data) yang telah dikumpulkan dan tidak berdasarkan dugaan-dugaan.

Oleh karena itu, kegiatan penilaian ini harus dilakukan pada dua tingkatan konsepsional. Pertama, pada tingkat administrasi dilakukan "administrative evaluating" yang bersifat menyeluruh dan mencakup semua tingkatan hierarki dan aspek kegiatan. Kedua, pada tingkat manajerial, terutama "middle dan supervisory management dilakukan managerial evaluation yang lebih sempit ruang lingkupnya jika dibandingkan dengan "administratve evaluating"karena tertuju pada hierarki yang bersifat separtemental aau sektoral saja (kegiatan-kegiatan khusus). (Burhanuddin, 1994: 97).

Sejalan dengan pendapat di atas, Robert L Katz sebagaimana dikutip oleh Burhanuddin mengatakan bahwa keterampilan yang harus dimiliki oleh administrator atau pemimpin yang efektif adalah: keterampilan teknis (technical skill), keterampilan hubungan manusia (human relation skill), dan keterampilan konseptual (conceptual skill). Untuk memberikan jabaran lebih jelas terkait dengan kriterium keterampilan di atas, maka penulis uraikan satu persatu sesuai dengan yang dipaparkan oleh Danim sebagai berikut: (Burhanuddin, 1994: 97).

1. Keterampilan Teknis (technical skill)

Keterampilan teknis adalah keterampilan menerapkan pengetahuan teoretis ke dalam tindakan-tindakan praktis, kemampuan memecahkan masalah melalui taktik yang baik, atau kemampuan menyelesaikan tugas-tugas secara sistematis. Robert L Katz merinci keterampilan teknis ini ke dalam hal-hal sebagai berikut:

a) kemampuan menyusun laporan pertanggungjawaban.

b) kemampuan menyusun program tertulis.

c) keterampilan membuat data statistik madrasah.

d) keterampilan membuat keputusan dan merealisasikannya.

e) keterampilan mengetik.

f) keterampilan menata ruang.

g) keterampilan membuat surat.

h) Keterampilan Manusiawi (human skill)

Keterampilan hubungan manusiawi adalah kemampuan untuk menempatkan diri di dalam kelompok kerja dan keterampilan menjalin komunikasi yang mampu menciptakan kepuasan kedua belah pihak. Keterampilan yang ada hubungannya antara lain :
a) keterampilan menempatkan diri dalam kelompok;
b) keterampila menciptakan kepuasan pada diri bawahan;
c) sikap terbuka terhadap kelompok kerja;
d) kemampuan mengambil hati melalui keramah-tamahan;
e) penghargaan terhadap nilai-nilai etis;
f) pemerataan tugas dan tanggung jawab; dan iktikad baik, adil, menghormati, dan menghargai orang lain. (Danim Sudarwan, 2004: 54). 


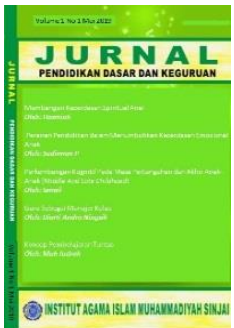

JURNAL

Pendidikan Dasar dan Keguruan

Volume 6, No. 1, 2021

ISSN (print) : 2527-578X

ISSN (Online): 2715-6818

Homepage : http://journal.iaimsinjai.ac.id/index.php/JPDK

2. Keterampilan konseptual (conceptual skill)

Keterampilan konseptual adalah kecakapan untuk memformulasikan pikiran, memahami teori-teori, melakukan aplikasi, melihat kecendrungan berdasarkan kemampuan teoretis dan yang dibutuhkan di daklam dunia kerja.

Keterampilan konseptual antara lain tercermin dalam pemahman terhadap teori secara luas dan mendalam, kemampuan mengorganisasi pikiran, keberanian mengeluarkan pendapat secara akademik, dan kemampuan mengkorelasikan bidang ilmu yang dia miliki dengan berbagai situasi.

\subsubsection{Kriteria-kriteria Kepemimpinan Madrasah Ibtidaiyah}

Adapun kriteria kepemimpinan yang dimaksud adalah pemimpin yang efektif seperti yang disebutkan oleh Burhanuddin dalam bukunya kepemimpinan dan prilaku organisasi adalah :

Pemimpin yang jujur, takwa terhadap tuhan yang maha esa, integritas, vitalitas fisik dan mental, kecerdasan, kearifan, bertanggung jawab, kompeten, memahami kebutuhan pengikutnya, keterampilan interpersonal, kebutuhan untuk berprestasi, mampu memotivasi dan memberi semangat, mampu memecahkan masalah, meyakinkan, memiliki kapasitas untuk menang, memiliki kapasitas untuk mengelola, memutuskan, menentukan prioritas, mampu memegang kepercayaan, memiliki pengaruh, mampu beradaptasi/memiliki fleksibilitas. (Burhanuddin, 1994: 38).

Berdasarkan uraian di atas dapat disimpulkan bahwa kriteria kepemimpinan semacam ini sangatlah diharapkan bagi pemimpin yang efektif dalam menjalankan tugas-tugasnya sebagai seorang pemimpin. Setiap pemimpin yang efektif harus berusaha mewujudkan kreteria tersebut. Disamping itu juga, pemimpin yang efektif harus berusaha mewujudkan fungsi kepemimpinannya sebagai seorang pemimpin, dan pemimpin yang efektif juga sangat dipengaruhi oleh kepribadian pemimpinnya.

Selain itu, hal lain yang perlu diperhatikan sebagai seorang pemimpin efektif adalah memiliki integritas moral yang tinggi, seorang pemimpin hendaknya bisa digugu dan ditiru, ia adalah pemimpin bagi dirinya sendiri sekaligus sebagai pemimpin bagi bawahan yang dipimpinnya. Hal ini menurut penulis merupakan prasyarat bagi seorang pemimpin, karena kesatuan (unifikasi) antara ucapan seorang pemimpin, baru bisa akan diikuti oleh bawahannya manakala sejalan dengan apa yang diperbuatnya.

Begitu juga dengan kepala madrasah sebagai seorang pemimpin pendidikan haruslah memiliki atau mencerminkan kriteria diatas untuk membangun kerjasama yang baik dengan masyarakat di madrasah dan untuk mencapai suatu tujuan yang diharapkan. Seorang kepala madrasah yang baik dapat dilihat dari kriteria-kriteria tersebut.

\subsubsection{Tugas dan Peran Kepala Madrasah sebagai Pemimpin}

Sebagai seorang kepala Madrasah tentunya harus mengetahui dan mengerti tugas dan peranannya sebagai seorang pemimpin, adapun tugas dan peranan kepala madrasah sebagai pemimpin adalah sebagai berikut:

a. Tugas Kepala Madrasah sebagai Pemimpin

Tidak semua kepala madrasah mengerti maksud kepemimpinan, kualitas serta fungsi-fungsi yang harus dijalankan oleh pemimpin pendidikan. Setiap orang yang memberikan sumbangan bagi perumusan dan pencapaian tujuan bersama adalah pemimpin, namun individu yang mampu memberi sumbangan yang lebih besar terhadap perumusan tujuan serta terhimpunnya suatu kelompok di dalam kerja sama mencapainya, dianggap sebagai pemimpin yang sebenarnya. Orang yang memegang jabatan kepala madrasah adalah pemimpin pendidikan.

Tugas dan tanggung jawab kepala madrasah dapat digolongkan menjadi dua yaitu bidang administrasi dan bidang supervisi, adapun yang dimaksud adalah sebagai berikut:

1. Tugas kepala madrasah dalam bidang administrasi dapat digolongkan menjadi enam bagian yaitu:

a) Pengelolaan pengajaran pokok.

Pengelolaan pengajaran ini merupakan dasar kegiatan dalam melaksanakan tugas 
Volume 6, No. 1, 2021

ISSN (print) : 2527-578X

ISSN (Online): 2715-6818

Homepage : http://journal.iaimsinjai.ac.id/index.php/JPDK

b) Pengelolaan kepegawaian

Termasuk dalam bidang ini yaitu menyelenggarakan urusan-urusan yang berhubungan dengan penyeleksian, pengangkatan kenaikan pangkat, cuti, perpindahan dan pemberhentian anggota staf madrasah, pembagian tugas-tugas di kalangan anggota staf madrasah, masalah jaminan kesehatan dan ekonomi, penciptaan hubungan kerja yang tepat dan menyenangkan, masalah penerapan kode etik jabatan.

c) Pengelolaan kesiswaan

Dalam bidang ini kegiatan yang nampak adalah perencanaan dan penyelenggaran murid baru, pembagian murid atas tingkat-tingkat, kelas-kelas atau kelompok-kelompok (grouping), perpindahan dan keluar masuknya murid-murid (mutasi), penyelenggaraan pelayanan khusus (special services) bagi murid, mengatur penyelenggaraan dan aktivitas pengajaran, penyelenggaran testing dan kegiatan evaluasi, mempersiapkan laporan tentang kemajuan masalah disiplin murid, pengaturan organisasi siswa, masalah absensi, dan sebagainya.

d) Pengelolaan gedung dan halaman

Pengelolaan ini menyangkut usaha-usaha perencanaan dan pengadaan, inventarisasi, pengaturan pemakaian, pemeliharaan, rehabilitasi perlengkapan dan alat-alat material madrasah, keindahan serta kebersihan umum, usaha melengkapi yang berupa antara lain gedung (ruangan madrasah), lapangan tempat bermain, kebun dan halaman madrasah, meubel madrasah, alat-alat pelajaran klasikal dan alat peraga, perpustakaan madrasah, alatalat permainan dan rekreasi, fasilitas pemeliharaan madrasah, perlengkapan bagi penyelenggaraan khusus, transportasi madrasah, dan alat-alat komunikasi,

e) Pengelolaan keuangan

Dalam bidang ini menyangkut masalah-masalah urusa gaji guru-guru dan staf madrasah, urusan penyelenggaraan otorisasi madrasah, urusan uang madrasah dan uang alatalat murid-murid, usaha-usaha penyediaan biaya bagi penyelenggaraan pertemuan dan perayaan serta keramaian.

f) Pengelolaan hubungan madrasah dan masyarakat

Untuk memperoleh simpati dan bantuan dari masyarakat termasuk orang tua muridmurid, dan untuk dapat menciptakan kerjasama antara madrasah-rumah- dan lembagalembaga sosial.

2. Tugas Kepala Madrasah Dalam Bidang Supervisi

Kepala Madrasah bertugas memberikan bimbingan, bantuan, pengawasan dan penilaian pada masalah-masalah yang berhubungan dengan teknis penyelenggaraan dan pengembangan pendidikan pengajaran yang berupa perbaikan program dan kegiatan pendidikan pengajaran untuk dapat menciptakan situasi belajar mengajar. Tugas ini antara lain :

a) Membimbing guru-guru agar mereka dapat memahami secara jelas tujuan-tujuan pendidikan pengajaran yang hendak dicapai dan hubungan antara aktivitas pengajaran dengan tujuantujuan.

b) Membimbing guru-guru agar mereka dapat memahami lebih jelas tentang persoalanpersoalan dan kebutuhan murid.

c) Menyeleksi dan memberikan tugas-tugas yang paling cocok bagi setiap guru sesuai dengan minat, kemampuan bakat masing-masing dan selanjutnya mendorong mereka untuk terus mengembangkan minat, bakat dan kemampuannya.

d) Memberikan penilaian terhadap prestasi kerja madrasah berdasarkan standar-standar sejauh mana tujuan madrasah itu telah dicapai.

3. Peran Kepala Madrasah sebagai Pemimpin Pendidikan

Menurut Purwanto, mengatakan bahwa seorang kepala madrasah mempunyai sepuluh macam peranan, yaitu : "Sebagai pelaksana, perencana, seorang ahli, mengawasi hubungan antara anggota-anggota, mewakili kelompok, bertindak sebagai pemberi ganjaran, bertindak 
sebagai wasit, pemegang tanggung jawab, sebagai seorang pencipta, dan sebagai seorang ayah." (Ngalim Purwanto.1984: 56). berikut :

Untuk lebih jelasnya, akan diuraikan peranan kepala madrasah sebagai pemimpin, sebagai

1. Sebagai pelaksana (executive). Seorang pemimpin tidak boleh memaksakan kehendak sendiri terhadap kelompoknya. Ia harus berusaha memenuhi kehendak dan kebutuhan kelompoknya, juga program atau rencana yang telah ditetapkan bersama

2. Sebagai perencana (planner). Sebagai kepala madrasah yang baik harus pandai membuat dan menyusun perencanaan, sehingga segala sesuatu yang akan diperbuatnya bukan secara sembarangan saja, tatapi segala tindakan diperhitungkan dan bertujuan.

3. Sebagai seorang ahli (expert). Ia haruslah mempunyai keahlian terutama yang berhubungan dengan tugas jabatan kepemimpinan yang dipegangnya.

4. Mengawasi hubungan antara anggota-anggota kelompok (contoller of internal relationship). Menjaga jangan sampai terjadi perselisihan dan berusaha mambangun hubungan yang harmonis.

5. Mewakili kelompok (group representative). Ia harus menyadari, bahwa baik buruk tindakannya di luar kelompoknya mencerminkan baik buruk kelompok yang dipimpinnya.

6. Bertindak sebagai pemberi ganjaran / pujian dan hukuman. Ia harus membesarkan hati anggotaanggota yang bekerja dan banyak sumbangan terhadap kelompoknya.

7. Bertindak sebagai wasit dan penengah (arbitrator and modiator). Dalam menyelesaikan perselisihan atau menerima pengaduan antara anggota-anggotanya ia harus dapat bertindak tegas, tidak pilih kasih atau mementingkan salah satu anggotanya.

8. Pemegang tanggung jawab para anggota kelompoknya. Ia haruslah bertanggung jawab terhadap perbuatan-perbuatan anggota-anggotanya yang dilakukan atas nama kelompoknya.

\section{Simpulan}

Karakteristik adalah sesuatu yang khas atau mencolok dari seseorang ataupun sesuatu benda atau hal. Karakteristik adalah mengacu kepada karakter dan gaya hidup seseorang serta nilai-nilai yang berkembang secara teratur sehingga tingkah laku menjadi lebih konsisten dan mudah di perhatikan. Sedangkan kepemimpinan pada dasarnya berarti kemampuan untuk memimpin, kemampuan untuk menentukan secara benar apa yang harus dikerjakan.

Pada dasarnya karakteristik kepemimpinan madrasah ibtidaiyah adalah suatu gambaran obyektif yang hampir terjadi di seluruh madrasah, hal itu dapat dilihat dari keterampilan-keterampilan kepemimpinan madrasah, kriteria-kriteria kepemimpinan madrasah, tugas dan peranan kepala madrasah sebagai pemimpin.

Dengan terbitnya tulisan ini, penulis sangat berharap kepada seluruh khalayak pembaca untuk bijak dalam mnyajikan tulisan ini. Penulis sangat yakin, masih banyak sekali terdapat kekurangankekurangan dalam penulisan ini, penulis sangat berharap ada saran dan masukan berupa penelitian penelitian lanjutan.

\section{Daftar Pustaka}

Arikunto, Suharsimi. (2006). Prosedur Penelitian, Suatu Pendekatan Praktik. Jakarta: Rineka Cipta

Burhanuddin. (1994) Analisis Administrasi Manajemen dan Kepemimpinan Pendidikan, Malang: Bumi Aksara.

Davis, Keith and Newstrom, W, John. (1985). Human Behaviour at Work : Organizational Behaviour. New York Mc: Graw-Hill Inc 
Gibson, L, James. (1988). Organisasi Perilaku, Struktur, Proses, Alih bahasa: Djarkasih. Jakarta : Erlangga.

Kountur, Ronny. (2004). “Metode Penelitian Untuk Penulisan Skripsi Dan Tesis”,Jakarta : PPM

Moleong, Lexy J. (2005). Metode Penelitian Kualitatif (edisi revisi). Bandung : Remaja Rosdakarya.

Ngalim, Purwanto. (1984). Prinsip-Prinsip Dan Teknik Evaluasi Pengajaran. Bandung: PT Remaja Rosdakarya.

Samargono, (2004). Metodelogi Penelitian Pendidikan. Jakarta: PT Rineka Cipta. 2004.

Sangadji, Mamang, Etta dan Sopiah,(2010). Metodologi Penelitian: Pendekatan Praktis Dalam Penelitian. Yogyakarta: CV. Andi Offset.

Sudarwan, Danim. (2004). Motivasi Kepemimpinan dan Efektivitas Kelompok. Jakarta; Rineka Cipta.

Sugiyono. (2010). Metode Penelitian Pendidikan (Pendekatan Kuantitatif, Kualitatif dan R\&D). Bandung: Alfabeta.

Vroom, H, Victor, dan G, Arthur Jago. (1988). The New Leadership: Managing Participation in Organizations. Englewood Cliffs. New Jersey: Prentice Halls. 